\title{
CURRICULA, HISTORY OF SCIENCE AND SCIENCE EDUCATION
}

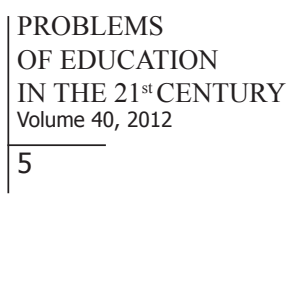

\author{
Raffaele Pisano \\ ESHS (European Society for the History of Science), Italy \\ E-mail: pisanoraffaele@iol.it
}

\section{Dear Readers,}

Generally speaking, current school science curricula have been constructed for the purpose of preparing students for university and college scientific degrees. Such education does not meet the needs of the majority of students who will not pursue tertiary studies in science or even science-related fields. These students require knowledge of the main ideas and methodologies of science. It seems that the didactics of scientific disciplines across Europe have failed to solve the "crisis" between scientific education and European social and economic development. This is generally recognized in the reports published concerning science education in Europe (Rocard report, etc.) which propose new strategies to be implemented in teaching through the identification and promotion of Inquiry based Science Education (IBSE) and other strategies. It is timely that there is a multi disciplinary dialogue exchanging new ideas and proposals between educational researchers, historians, philosophers and learning theorists.

The didactics of scientific disciplines such as mathematics, physics, chemistry, biology and earth sciences hardly and generally recognized that science is an important component of the European cultural heritage and provides the only well-grounded explanations we have of structures, events, and processes in the material and social world. Clearly some understanding of the practices and processes of science is essential to engage with many of the issues confronting contemporary society. However, in recent times fewer young people seem to be interested in science and technical subjects.

In my previous editorials and articles, published in JBSE and PEC etc., I included remarks on the emergency of change teaching both foundations and textbooks. A debate and suggestions proposed among science scholars, teachers and historians on the matter seem indeed necessary from an ethic and professional point of view. Thus, what kind of scientific cultural background does it take to teach how science works? And what about history of science in curricula of secondary school? Why is there this lack of engagement in science? Does the problem lie in wider socio-cultural changes, and the ways in which young people in the European countries now live and wish to shape their lives? Or is it due to failings within science education itself? The history and epistemology of science help to understand evolution/involution of mathematical and physical sciences in the interpretation-modelling of a phenomenon and its interpretationdidactic-modelling, and how the interpretation can change for a different use of mathematical: e.g., mathematics à la Cauchy, non-standard analysis, constructive mathematics in physics. The learning-teaching modelling is important to discuss efficacy and power both from educational point of view and the need of mathematics and physics teachers' education.

Following this standpoint, based on an original idea (2010) by Ilaria Gaudiello (ESHS/ University of Paris 8-CHArt-LUTIN, Paris) and I (ESHS/Cirphles-ENS Paris), an international workshop Science Studies And Science Education: How Science Works - And How To Teach It, was co-organized by the latter with Department of Science Studies and the Centre for Science Education (Aarhus University) in Denmark on 23-25 June, 2011. The workshop followed one 
PROBLEMS

OF EDUCATION

IN THE $21^{\text {st }}$ CENTURY

Volume 40,2012

of the interests of the ESHS: the role and circulation of history of sciences in Europe starting from secondary school, as well. The international workshop also aimed to debate on the history and philosophy of science teaching into the classroom. Nevertheless, crucial questions often discussed both in this book series and correlated JBSE live: what about the importance of introducing the history of foundations of science as an essential part of the culture of teaching education to the extent of considering such a discipline - in its turn - as an indissoluble pedagogical element of history and culture? And in this sense, by introduction of history of foundations of science, how can the role played by textbook for secondary school change? Thus, if a textbook changes, how the teachers should change? What kind of profile? Finally, in my opinion, we should not loose the certainty of a critical thought on science... turning from teaching based on principles to teaching (also) based on large and cultural foundational themes related with ad hoc foundations-sociological-epistemological aspects of science.

Prominent and high quality secondary school teaching and university-academic centres research programs are crucial for the development of interest in the history of science and its cultural implications. On occasion of the $5^{\text {th }}$ International Congress of The European Society for History of Science (www.eshs.org) which will be held in Athens (Greece) on 1-3 November, 2012 in Athens: 32 symposia on history of sciences correlated with science education philosophy, epistemology, historical epistemology and anthropology of sciences are available for the $5^{\text {th }}$ International ESHS conference. Particularly one of the symposium aims will be to discuss contributions from history and philosophy of sciences and science education in the curricula of European secondary high schools. Next an international Congress on history of physics and astronomy (XXXII SISFA 2012) will be held in Roma (27-29 September, 2012 www.rcths.eu) where topics on history of science and science education will be discussed, as well.

Received: February 29, 2012

Accepted: March 18, 2012

Raffaele Pisano

PhD, Cirphles, École Normale Supérieure Paris, France.

ESHS (European Society for the History of Science).

Research Centre for the Theory and History of Science, University of West

Bohemia, Czech Republic.

E-mail: pisanoraffaele@iol.it

Website: http://www.historyofscience.it 